\title{
Indicators to Evaluate the Social Dimensions of the Recreational Fishery in the Great Lakes
}

Nadine Heck*

Department of Natural Resources, Cornell University, Fernow Hall, Ithaca, New York 14853, USA; and Institute of Marine Sciences, University of California-Santa Cruz, 1156

High Street, Santa Cruz, California 95064, USA

*Corresponding author: nheck@ucsc.edu

Richard C. Stedman

Department of Natural Resources, Cornell University, Fernow Hall, Ithaca, New York 14853, USA

Marc Gaden

Great Lakes Fishery Commission, 2100 Commonwealth Boulevard, Ann Arbor, Michigan 48105, USA

\section{Abstract}

Natural resource management agencies increasingly engage in monitoring and evaluation activities to become more explicit and transparent about their activities and to demonstrate management achievements. As fishery management focuses on fish resources and the people using these resources, evaluating management performance requires assessing both environmental and human-centered outcomes of a fishery. Our paper addresses the current lack of indicators to evaluate the social dimensions of the recreational fishery in the Great Lakes. We identified management outcomes and evaluation indicators for the social dimensions of the fishery through semistructured interviews with fishery managers. Our study finds that fishery managers identified desired management outcomes and indicators at three distinct levels: individual anglers, local communities, and Great Lakes states and provinces. Managers' input on outcomes and indicators was key to clarifying generic management goals such as "happy anglers." Desired outcomes also revealed that managers' understanding of management effectiveness goes beyond current management goals. Regular adaptation of management goals for the fishery might be critical to make sure that goals reflect what managers would like to achieve. We also suggest extending evaluation efforts beyond the assessment of management goals. Including ecological, social, and economic trends in the basin that influence the performance of the fishery could help managers understand and predict the effect of contextual changes in the basin on the fishery over time.

This is the accepted manuscript of an article published by Taylor \& Francis in the North American Journal of Fisheries Management, available online: https://www.tandfonline.com/doi/abs/10.1080/02755947.2016.1141126?journalCode=ujfm20 


\section{INTRODUCTION}

Fishery management, including recreational fisheries, is increasingly moving towards ecosystem-based management approaches that recognize the ecological and social complexity of fisheries (Hunt et al. 2013). Along with the diversification of desired outcomes, managers need to understand and identify what fishery management "success" means in light of this complexity (Hilborn 2007). In many instances, management goals are diverse and broad. Detailed information identifying successful achievement of management goals is often lacking, particularly for social dimensions of fisheries (Bossel 2001; Hilborn 2007; Samhouri et al. 2013; Yang et al. 2014). Subsequently, understanding and identifying what fishery management success means and how effectiveness will be measured over time can be difficult (Hilborn 2007; Day 2008; C. Syms and M. Carr, paper read at the North American Commission for Environmental Cooperation workshop, 2001). Management effectiveness commonly refers to the degree that management actions are achieving goals and objectives (Pomeroy et al. 2004; Hockings et al. 2006).

Management goals or statements alone often are not detailed enough to directly serve as a basis for evaluation exercises. Additional information is often needed to develop a set of indicators that can be used to evaluate performance over time (Alder et al. 2002; Pomeroy et al. 2004).

Indicators in general are variables that help to simplify complex information and to measure management performance (Garcia et al. 2000; Bossel 2001). Effective indicators should be understandable (FAO 1999; United Nations 2007), relevant to management efforts (FAO 1999; OECD 2008), measurable (United Nations 2007), collected cost-effectively (e.g., from existing data sources; United Nations 2007), be responsive and sensitive to changing conditions (OECD 2008), and be context specific (Parkins et al. 2001; FontalvoHerazo et al. 2007). Because fisheries are dynamic systems, performance indicators probably will change over time as management goals and objectives or governance approaches evolve (Fontalvo-Herazo et al. 2007).

The assessment of indicators can serve multiple purposes, such as measuring performance against specific management objectives or enhancing communication, transparency, and accountability (Garcia et al. 2000; Samhouri et al. 2013). Managers, for example, may use outcomes of an indicatorbased evaluation to report achievements and to increase accountability and transparency of management actions and use of resources (Day 2008).

Most fishery indicators have been developed to evaluate biological or ecological performance or focus on commercial fisheries in marine areas (e.g., Bonzon 2000; Chong 2000; Garcia et al. 2000; Hundloe 2000; Ward 2000; Methratta and Link 2006; Kershner et al. 2011; Yang et al. 2014). Comparatively less is known about indicators to assess social, economic, or cultural outcomes of recreational fisheries. Our study addresses this gap by developing performance indicators to evaluate the social dimensions of the recreational fishery in the Great Lakes basin. 
We developed these indicators on the basis of fishery managers' understanding of management effectiveness. The study therefore reflects only the views of fishery managers.

The Great Lakes basin consists of five connected lakes (Superior, Huron, Michigan, Erie, and Ontario) that make up the largest surface freshwater system in the world (USEPA 2015). Fishery management across the basin is shared among federal, state, and provincial government agencies (Gaden et al. 2012). Multiple ecological and social trends in the basin potentially affect the fishery, including climate change (Cline et al. 2013; Cline et al. 2014; Farmer et al. 2015), nutrient pollution (Michalak et al. 2013; Scavia et al. 2014), spread of pathogens and aquatic invasive species (Bain et al. 2010; Kilian et al. 2012; Kelly et al. 2013), and social and economic changes associated with human migration and economic trends (Breffle et al. 2013).

Most research and monitoring efforts in the basin have focused on ecological, chemical, and physical indicators (International Joint Commission 2014). Examples include indicators of water quality, air quality, sediments, benthic community condition, and fish health (e.g., contaminant concentration trends in top predator fish and overall effects of toxic chemicals on fish and fishconsuming wildlife; USEPA 2012). Systematic monitoring of social, economic, cultural, and governance indicators for the Great Lakes fishery is lacking. Our study addresses this gap by developing indicators to evaluate management effectiveness for the social dimensions of the recreational fishery, based on information needs of fishery managers. To achieve this aim, we assessed (1) fishery managers' understanding of the social dimensions of the fishery in terms of values and goals; (2) fishery managers' understanding of management effectiveness for the social dimensions of the fishery; and (3) fishery managers' information needs for evaluating management effectiveness.

\section{METHODS}

We conducted 38 face-to-face semi-structured interviews with fishery managers from all federal, state, provincial, and tribal jurisdictions throughout the Great Lakes (Table 1) between March 20 and May 24, 2012. We used a semi-structured interview guide to ensure that all participants answered the same general set of questions but also allowed deeper exploration of participants' specific perspectives. Interviews lasted between 40 and $70 \mathrm{~min}$. We assured all participants that we would treat their comments confidentially and not attribute comments to them individually in any report or publication. The interviews centered on the following questions: (1) What values do managers associate with the recreational fishery? (2) What are current management goals that guide recreational fishery management in the Great Lakes? (3) How would fishery managers define management effectiveness for the social dimensions? (4) What kind of information would mangers assess to know whether desired outcomes have been achieved?

With the consent of participants, interviews were audio-recorded and transcribed verbatim. We analyzed the transcripts using computer software, Atlas.ti 7, designed to assist in the analysis of qualitative data. Consistent with steps pretested by Miles and Huberman (1984), interview data 
were coded through an on-going process. We first used pattern-coding to identify broad themes, contexts, and relationships; then open-coding to sort these sentiments in more detail; and finally cluster-coding to take the detailed codes and reconstitute them into more general themes (Strauss and Corbin 1990:101-121; Auerbach and Silverstein 2003). Two professors in the Department of Natural Resources at Cornell University with extensive expertise in human dimensions of fisheries cross-checked the codes to increase reliability of the codes and the coding process. We also conducted two focus groups with fishery managers we had interviewed previously. Each group included eight participants and lasted about $90 \mathrm{~min}$. We distributed a summary of our findings that came out of the interviews to participants in the focus groups prior to the meeting and used the groups to discuss our findings. Participants in the focus groups confirmed that our interpretations of the interviews were valid and did not require any revisions. Interview excerpts are included in the results section to support the essence of a point and the range of perspectives.

TABLE 1. Interview participants by job description and affiliation $(N=38)$.

\begin{tabular}{llc}
\hline Job position & Institution & $\begin{array}{c}\text { Number of } \\
\text { interviewees }\end{array}$ \\
\hline Biologist & Federal & 4 \\
& State & 6 \\
& Provincial & 2 \\
Fishery manager & Tribal & 1 \\
& State & 17 \\
Senior fishery supervisor & Provincial & 4 \\
& Tribal & 1 \\
& State & 2 \\
& Provincial & 1 \\
\hline
\end{tabular}

\section{RESULTS}

Evaluation exercises are usually context sensitive. Subsequently, we first asked managers about the values they associate with the recreational fishery and the current management goals that guide fishery management.

\section{Values Associated with the Recreational Fishery}

Fishery managers in our study felt that the recreational fishery provides multiple social, cultural, and economic values to anglers and local communities (Figure 1). Anglers value recreation, experiencing nature, and educating children. Participants pointed out that recreational fishing offers the opportunity to socialize, spend quality time with friends and family, and teach children how to fish. Managers mentioned, "When I think of fishing, I think of relaxing, retreat, reaping the benefit of my 9-5 job." Fishery managers also felt that the fishery 
provides opportunities to continue family tradition, as "fishing has been passed down from generation to generation."

In addition, fishery managers thought that the fishery contributed to the general quality of life in local communities and is part of the cultural heritage in the basin. Fishery managers cited multiple nonuse values to people in the basin, including an existence value, as the fishery appears to be "intrinsically valuable[;] if we didn't have fisheries in the Great Lakes, we really wouldn't be what we are." Aesthetic values referred to the existence of fishing boats on the lakes and the enjoyment people get from watching them pass by. Managers also believed people are sensitive to the need to maintain the existence of the fishery for future generations.

\section{Fishery Management Goals}

When asked about current management goals, fishery managers cited a range of economic and social goals. These goals were less diverse and less specific than the fishery values (Figure 2).

Economic goals focused on fostering economic development in local communities and sustaining income for recreational fishing-charter operators. Social goals included providing opportunities for recreational fishing and ensuring that anglers are satisfied with their fishing experience. Another goal emphasized education of anglers about the Great Lakes ecosystem, the fishery, mandatory regulations (e.g., bag limits), and voluntary recommendations about appropriate behavior (e.g., cleaning bait buckets to prevent spread of aquatic invasive species).

\section{Fishery values}

\begin{tabular}{lll}
\hline &
\end{tabular}

FIGURE 1. Social dimension values attached to the recreational fishery, as identified by interviewed fishery managers. 


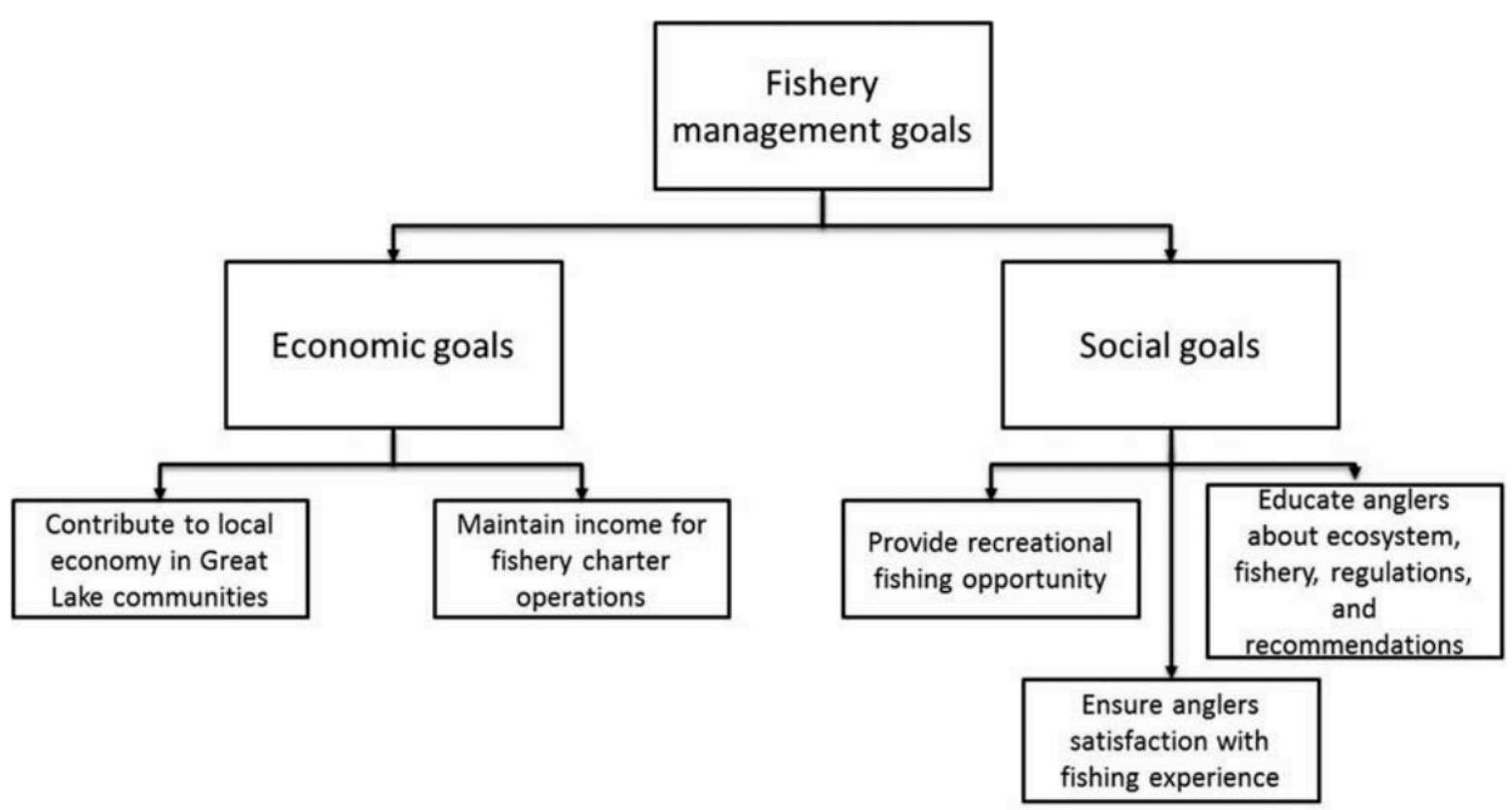

FIGURE 2. Fishery managers' management goals for the social dimensions of the recreational fishery.

\section{Management Outcomes and Performance Indicators}

To identify outcomes for the social dimensions of the fishery, we asked fishery managers how they would define management effectiveness. Fishery managers identified desired outcomes at three distinct levels: individual anglers, local communities, and state agencies (Figure 3). The greatest diversity of desired outcomes referred to anglers themselves and their fishing experiences. Desired outcomes at the community level included economic and cultural outcomes. At the state level, fishery managers mentioned only economic outcomes. We also developed a set of specific indicators based on managers' information needs to assess cited outcomes (Figure 4). These indicators clarified generic management goals such as anglers' satisfaction, provision of opportunities for recreational fishing, and outcomes of education efforts (e.g., knowledge about ecosystem in the Great Lakes). A few indicators did not directly relate to management goals, such as anglers' stewardship, cultural importance for local communities, and the economic impact of the fishery on Great Lakes states' economies. We were able to translate the majority of comments into measurable units such as number of anglers, number of license sales, and fishing days per year. Other indicators, such as peer pressure to comply with regulations, would need to be refined further to become measurable.

The greatest diversity of information needs and indicators focused on individual anglers, emphasizing their satisfaction with the fishery, their fishing patterns, stewardship, and awareness and knowledge. Indicators to assess fishing patterns, for example, included the number of anglers, number of license sales, angler hours and days per year, and number of people on charter boats. Indicators to assess awareness and knowledge referred to anglers' knowledge about the ecosystem, state of the fish resources, and fishing regulations. An 
indicator to evaluate stewardship was peer pressure among anglers to comply with regulations and behavioral recommendations.

Indicators to assess cultural and economic management outcomes at the community level included the existence and number of fishery museum and fishery-based events, such as cookoffs and local fish food festivals, where "all the local chefs come in from a large metropolitan area and prepare fish, ... and promote ... the local food culture." Another cultural indicator was the presence of fishery-related topics in local newspapers. These sections should help keep people informed about the fishery and foster interaction and engagement among anglers to create a sense of community. Economic indicators at the community level included investment in local fishery-dependent businesses, the number of fishery-related business closures, unemployment rates in recreational fishing charter operations, the number of fisherydependent industries such as the bait shops, and the economic impact from fishery-related sectors such as gasoline, lodging, bait and tackle stores, restaurants, and other supplies.

Participants stressed that they would also evaluate economic indicators at the state/provincial level. Fishery managers thought that recreational fishing makes "a huge contribution to the economy of the state" and "brings in tourism dollars that enhance the life of the people" around the Great Lakes basin. Subsequently, fishery managers felt the need to evaluate the contribution of the recreational fishing sector to state economies in general and to revenue from license sales more specifically. Ideally, fishery management would maintain or enhance these revenues, thus demonstrating the contribution of the fishery to the economy in the basin. 


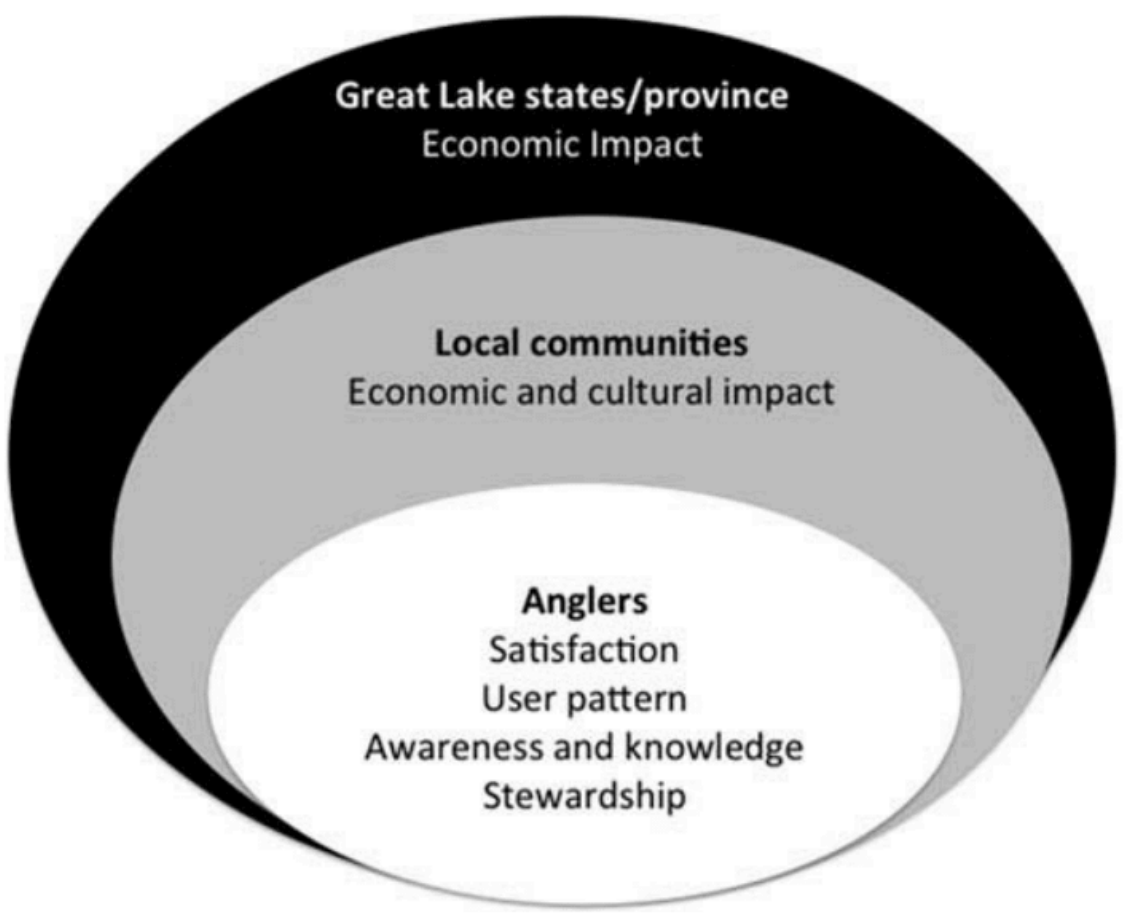

FIGURE 3. Fishery managers' desired management outcomes for the social dimensions of the recreational fishery. 

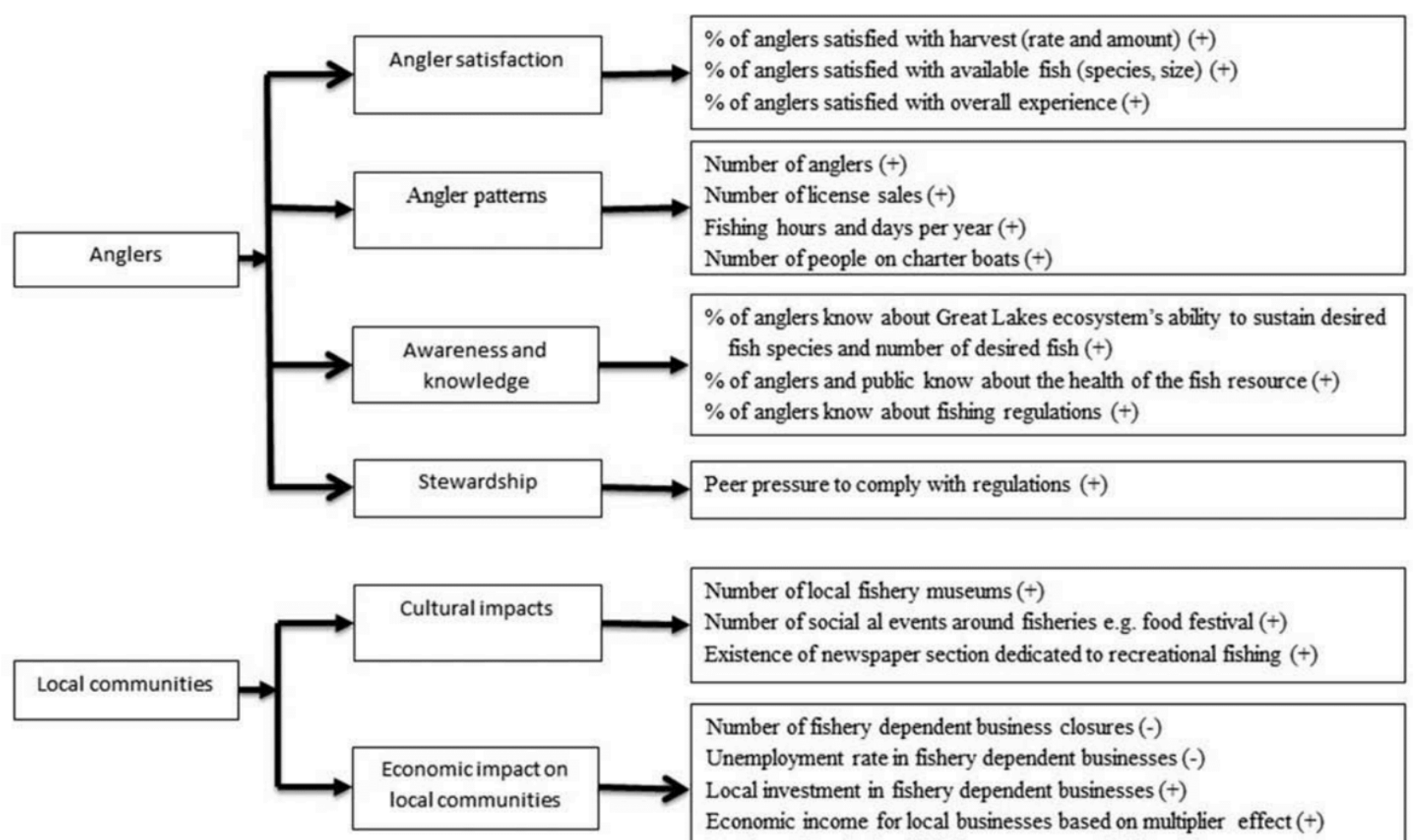

Number of fishery dependent business closures (-)

Unemployment rate in fishery dependent businesses (-)

Local investment in fishery dependent businesses $(+)$

Economic income for local businesses based on multiplier effect $(+)$

Number of marketing initiatives to promote fishing $(+)$

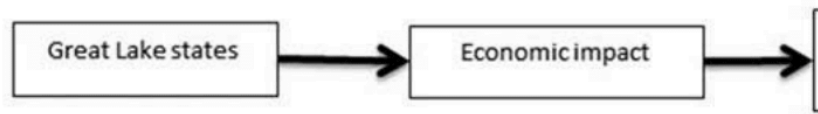

$\%$ of state' s economy that comes from the fishery $(+)$

Revenue from license sales (+)

FIGURE 4. Indicators to evaluate social dimensions of the recreational fishery, as derived from fishery managers interviewed for this study

\section{DISCUSSION}

In recent years, natural resource management agencies have come under pressure to become more explicit and transparent about their activities and to engage in monitoring and evaluation exercises that would demonstrate management achievements (Nielsen and Knuth 2012). In the Great Lakes recreational fishery, most evaluation efforts so far seem to focus on ecological and biological indicators (International Joint Commission 2014). Such an approach, however, does not provide information on the achievement of social, cultural, or economic goals. Our study addressed this point and investigated what kind of information fishery managers seek to evaluate whether their management of the social dimensions of the fishery is effective.

Information on management achievements, including the social dimensions of the fishery, is important for multiple reasons. First, fishery managers increasingly need to demonstrate what outcomes they have achieved to increase management transparency and justify funding for fisheries. Information on management outcomes is also critical for adaptive management (Hollings 1978). Fishery managers need to understand whether their current management strategies are effective to achieve desired outcomes such as anglers' satisfaction with available species, access to the fishery, etc. If not, managers might consider revising their management 
objectives, strategies, or both. In addition, information on the social dimensions can help to understand interactions between ecological and social dimensions in the fishery. For example, monitoring the availability of specific native and nonnative species or the presence of invasive aquatic species with changes in management regulations as well as the number of anglers and their behavior (i.e., what species they target, and the frequency and location of their fishing behavior) might help to understand how these factors influence each other. Such an assessment would provide information on the social dimensions as linked to crucial ecological change and management effectiveness to gain a more complete understanding of the fishery as a socioecological system.

We found that eliciting managers' views on what constitutes management effectiveness was critical to clarify broad and generic management goals. Fishery managers, for example, cited specific outcomes that provided insights on "fuzzy" management goals such as "satisfied anglers." Such a refinement of management goals is a first step to identify desired management achievements in the absence of stated management objectives and targets.

The next step would be to translate management objectives into measurable units (Samhouri et al. 2013; Mascia et al. 2014). In our case, fishery managers expressed some information needs in measurable units such as number of license sales or number of anglers. Managers did not, however, define targets for these indicators, which would still be important to inform an evaluation exercise. In addition, fishery managers mentioned performance indicators, such as peer pressure to comply with regulations, or satisfaction with the fishing experience, that could be more refined for an evaluation exercise. Based on identified values, satisfaction with the fishing experience, for example, could include the opportunity to spend time outdoors, to socialize with family and friends, and to continue familiar traditions. Satisfaction with the experience, thus, could go beyond harvest rate and availability of species, because angling offers additional experiences that could influence satisfaction. This finding suggests that fishery managers might not know how to translate such performance indicators into measurable units or to set explicit management targets for social dimensions of the fishery. To some extent, this lack of understanding could stem from the fact that fishery managers in our study were trained primarily in ecology and biology, which is common in fishery management (Bunnefeld et al. 2011). Collaboration with academics working on social dimensions, or increasing in-house expertise in social and economic sciences, might help to identify management targets and measurable units for performance indicators that reflect social values. As experts trained in ecology and biology typically develop targets and thresholds for bioecological indicators, experts trained in the social sciences for fisheries should develop management targets for the social dimensions with the same scientific rigor and expertise.

Fishery managers also identified management outcomes and indicators at distinct levels, including individual anglers, local communities, and Great Lakes state economies. Examples of desired outcomes at the community and state level included a contribution to cultural heritage and economic sectors in local communities and Great Lake state economies. These outcomes did not explicitly reflect cited management goals. This finding shows that fishery managers have a much broader understanding of what they would like to achieve than is currently stated in 
management goals. Subsequently, fishery managers might want to adapt socially based management goals from time to time to make sure they reflect what managers actually would like to achieve. Otherwise, specific management achievements might go unnoticed.

The mismatch of goals and identified outcomes and indicators also touches on another important subject. Management effectiveness usually specifically deals with the achievement of stated management goals, objectives, and targets (Pomeroy et al. 2004). An assessment of specific indicators, however, can also demonstrate effects of management that are not necessarily tied to management goals (Syms and Carr, unpublished). Multiple studies, for example, have been undertaken to assess anglers' satisfaction with their fishing experience (e.g., Beardmore et al. 2014; McCormick and Porter 2014). Although this information does not necessarily provide information on the achievement of current management goals within a specific fishery, it still provides insights on effects of fishery management. Such research allows comparing and understanding management outcomes in different circumstances, such as for different geographic regions, distinct social and economic contexts, or specific fishing regulations.

Our study also finds that eliciting managers' information needs did not reveal indicators to evaluate how changes in the wider context of the fishery affect the achievement of fishery management outcomes. In the case of the recreational fishery in the Great Lakes, demographic changes in the basin, such as a decline in population, aging, greater ethnic diversity, and outmigration have the potential to radically change angler patterns (Breffle et al. 2013). Monitoring ambient factors of the broader social and environmental context (Mascia et al. 2014) and how these contextual factors affect angler patterns and related management outcomes could be critical to understanding and predicting changes in the performance of the fishery over time.

\section{ACKNOWLEDGEMENTS}

This study was funded by the Great Lakes Fishery Commission.

\section{REFERENCES}

Alder, J., D. Zeller, T. Pitcher, and R. Sumaila. 2002. A method for evaluating marine protected area management. Coastal Management 30:121-131.

Auerbach, C., and L. B. Silverstein. 2003. Qualitative data: an introduction to coding and analysis. New York University Press, New York.

Bain, M. B., E. R. Cornwell, K. M. Hope, G. E. Eckerlin, R. N. Casey, G. H. Groocock, R. G. Getchell, P. R. Bowser, J. R. Winton, W. N. Batts, A. Cangelosi, and J. W. Casey. 2010. Distribution of an invasive aquatic pathogen (viral hemorrhagic septicemia virus) in the Great Lakes and its relationship to shipping. PLoS (Public Library of Science) ONE [online serial] 5(4):e10156. 
Beardmore, B., L. M. Hunt, W. Haider, M. Dorow, and R. Arlinghaus. 2014. Effectively managing angler satisfaction in recreational fisheries requires understanding the fish species and the anglers. Canadian Journal of Fisheries and Aquatic Sciences 72:500-513.

Bonzon, A. 2000. Development of economic and social indicators for the management of Mediterranean fisheries. Marine Freshwater Research 51:493-500.

Bossel, H. 2001. Assessing viability and sustainability: a systems-based approach for deriving comprehensive indicator sets. Conservation Ecology [online serial] 5(2):art12.

Breffle, W. S., D. Muralidharan, R. P. Donovan, F. Liu, A. Mukherjee, and Y. Jin. 2013. Socioeconomic evaluation of the impact of natural resource stressors on human-use services in the Great Lakes environment: a Lake Michigan case study. Resources Policy 38:152-161.

Bunnefeld, N., E. Hoshino, and E. J. Milner-Gulland. 2011. Management strategy evaluation: a powerful tool for conservation? Trends in Ecology and Evolution 26:441-447.

Chong, K.-C. 2000. Using sustainability indicators to manage fisheries: experiences on the Bay of Bengal. Marine and Freshwater Research 51:523-527.

Cline, T. J., V. Bennington, and J. F. Kitchell. 2013. Climate change expands the spatial extent and duration of preferred thermal habitat for Lake Superior fishes. PLoS (Public Library of Science) ONE [online serial] 8 (4):e62279.

Cline, T. J., J. F. Kitchell, V. Bennington, G. A. Mckinley, E. K. Moody, and B. C. Weidel. 2014. Climate impacts on landlocked sea lamprey: implications for host-parasite interactions and invasive species management. Ecosphere [online serial] 5(6):art68.

Day, J. 2008. The need and practice of monitoring, evaluating and adapting marine planning and management-lessons from the Great Barrier Reef. Marine Policy 32:823-831.

FAO (Food and Agriculture Organization of the United Nations). 1999. Indicators for sustainable development of marine capture fisheries. FAO, Rome.

Farmer, T. M., E. A. Marschall, K. Dabrowski, and S. A. Ludsin. 2015. Short winters threaten temperate fish populations. Nature Communication [online serial] 6:art7724.

Fontalvo-Herazo, M. L., M. Glaser, and A. Lobato-Ribeiro. 2007. A method for the participatory design of an indicator system as a tool for local coastal management. Ocean and Coastal Management 50:779-795.

Gaden, M., C. Goddard, and J. Read. 2012. A history of multi-jurisdictional management of the shared Great Lakes fishery: transcending conflict and diffuse political authority. Pages 305-338 
in W. Taylor, A. Lynch and N. Leonard, editors. Great Lakes fishery management and policy. Michigan University Press, East Lansing.

Garcia, S. M., D. J. Staples, and J. Chesson. 2000. The FAO guidelines for the development and use of indicators for sustainable development of marine capture fisheries and an Australian example of their application. Ocean and Coastal Management 43:537-556.

Hilborn, R. 2007. Defining success in fisheries and conflicts in objectives. Marine Policy 31:153 158.

Hockings, M., S. Stolton, and F. Leverington. 2006. Evaluating effectiveness: a framework for assessing management of protected areas. International Union for Conservation of Nature, Gland, Switzerland.

Hollings, C. S. 1978. Adaptive environmental assessment. Wiley, Chichester, UK. Hundloe, T. J. 2000. Economic performance indicators for fisheries. Marine and Freshwater Research 51:485 491.

Hunt, L. M., S. G. Sutton, and R. Arlinghaus. 2013. Illustrating the critical role of human dimensions research for understanding and managing recreational fisheries within a socialecological system framework. Fisheries Management and Ecology 20:111-124.

International Joint Commission. 2014. Great Lakes ecosystem indicators report-a report of the IJC priority assessment of progress towards restoring the Great Lakes. International Joint Commission, Washington, D.C.

Kelly, N., K. Wantola, E. Weisz, and N. Yan. 2013. Recreational boats as a vector of secondary spread for aquatic invasive species and native crustacean zooplankton. Biological Invasions 15:509-519.

Kershner, J., J. F. Samhouri, C. A. James, and P. S. Levin. 2011. Selecting indicator portfolios for marine species and food webs: a Puget Sound case study. PLoS (Public Library of Science) ONE [online serial] 6(10): e25248.

Kilian, J., R. Klauda, S. Widman, M. Kashiwagi, R. Bourquin, S. Weglein, and J. Schuster. 2012. An assessment of a bait industry and angler behavior as a vector of invasive species. Biological Invasions 14:1469-1481.

Mascia, M. B., S. Pailler, M. L. Thieme, A. Rowe, M. C. Bottrill, F. Danielsen, J. Geldmann, R. Naidoo, A. S. Pullin, and N. D. Burgess. 2014. Commonalities and complementarities among approaches to conservation monitoring and evaluation. Biological Conservation 169:258-267. 
Mccormick, J. L., and T. K. Porter. 2014. Effect of fishing success on angler satisfaction on a central Oregon Rainbow Trout fishery: implications for establishing management objectives. North American Journal of Fisheries Management 34:938-944.

Methratta, E. T., and J. S. Link. 2006. Evaluation of quantitative indicators for marine fish communities. Ecological Indicators 6:575-588.

Michalak, A. M., E. J. Anderson, D. Beletsky, S. Boland, N. S. Bosch, T. B. Bridgeman, J. D. Chaffin, K. Cho, R. Confesor, I. Daloğlu, J. V. Depinto, M. A. Evans, G. L. Fahnenstiel, L. He, J. C. Ho, L. Jenkins, T. H. Johengen, K. C. Kuo, E. Laporte, X. Liu, M. R. Mcwilliams, M. R. Moore, D. J. Posselt, R. P. Richards, D. Scavia, A. L. Steiner, E. Verhamme, D. M. Wright, and M. A. Zagorski. 2013. Record-setting algal bloom in Lake Erie caused by agricultural and meteorological trends consistent with expected future conditions. Proceedings of the National Academy of Sciences of the USA 110:6448-6452.

Miles, M. B., and A. M. Huberman. 1984. Qualitative data analysis: a sourcebook of new methods. Sage Publications, Thousand Oaks, California.

Nielsen, L. A., and B. A. Knuth. 2012. Continuing your education in human dimensions. Pages 238-247 in D. J. Decker, S. J. Riley, and W. F. Siemer, editors. Human dimensions of wildlife management. Johns Hopkins University Press, Baltimore, Maryland.

OECD (Organisation for Economic Co-operation and Development). 2008. OECD Key environmental indicators. OECD, Paris.

Parkins, J., R. Stedman, and J. Varghes. 2001. Moving towards locally defined indicators of sustainability in forest-based communities: a mixed-method approach. Social Indicators Research 56:43-72.

Pomeroy, R., J. Parks, and L. Watson. 2004. How is your MPA doing? A guidebook of natural and social indicators for evaluating marine protected area management effectiveness. International Union for Conservation of Nature, Gland, Switzerland.

Samhouri, J. F., A. J. Haupt, P. S. Levin, J. S. Link, and R. Shuford. 2013. Lessons learned from developing integrated ecosystem assessments to inform marine ecosystem-based management in the USA. ICES Journal of Marine Science 71:1205-1215.

Scavia, D., J. David Allan, K. K. Arend, S. Bartell, D. Beletsky, N. S. Bosch, S. B. Brandt, R. D. Briland, I. Daloğlu, J. V. Depinto, D. M. Dolan, M. A. Evans, T. M. Farmer, D. Goto, H. Han, T. O. Höök, R. Knight, S. A. Ludsin, D. Mason, A. M. Michalak, R. Peter Richards, J. J. Roberts, D. K. Rucinski, E. Rutherford, D. J. Schwab, T. M. Sesterhenn, H. Zhang, and Y. Zhou. 2014. Assessing and addressing the re-eutrophication of Lake Erie: central basin hypoxia. Journal of Great Lakes Research 40:226-246. 
Strauss, A., and J. Corbin. 1990. Basics of qualitative research: grounded theory procedure and techniques, 2nd edition. Sage, Newbury Park, California. United Nations. 2007. Indicators of sustainable development: guidelines and methodologies.

United Nations, New York. USEPA (U.S. Environmental Protection Agency). 2012. Great Lakes monitoring. Available: http://www.epa.gov/grtlakes/glindicators/index.html. (February 2015).

USEPA (U.S. Environmental Protection Agency). 2012. Great Lakes monitoring. Available: http://www.epa.gov/grtlakes/glindicators/index.html. (February 2015).

USEPA (U.S. Environmental Protection Agency). 2015. Great Lakes. Available: http://www.epa.gov/greatlakes/. (August 2015).

Ward, T. J. 2000. Indicators for assessing the sustainability of Australia's marine ecosystems. Marine and Freshwater Research 51:435-446.

Yang, Y., R. Cullen, E. Hearnshaw, and I. A. Macdonald. 2014. An evaluation of self-governance in the New Zealand Bluff oyster fishery - the indicator system approach. Marine Policy 43:273282. 